\title{
ON THE COMPLEXITIES OF PROSECUTING ROBERT MUGABE AT THE INTERNATIONAL CRIMINAL COURT
}

\section{Everisto Benyera ${ }^{1}$}

\section{Introduction}

It was argued by Mamdani (20I0) that the International Criminal Court (ICC) was problematic right from its creation and it quickly became part of the transitional justice problem in Africa by, inter alia, being selective in its application of the law. The international justice system stands accused of failing to curb the scourge of violence and war in general and the protection of children, women and indigenous minorities in particular as the mechanisms put in place such as the ICC are embroiled in political turmoil thereby rendering them part of the problem and not the solution so desired by victims of human rights abuses. On such country which has witnessed human rights abuses on a continuous basis is Zimbabwe. Most of these human rights abuses such as the $1982 / 84$ Operation Gukurahundi atrocities were perpetrated mostly by state agencies thereby rendering those who were in command liable for prosecution to answer to charges of genocide.

A generation after Operation Gukurahundi and other episodes of state led human rights abuses such as Operation Chinyavada (I983), Operation Murambatsvina (2005), Operation Chipo Chiroorwa (2007) and Operation Mavhotera Papi (2008), (Benyera and Nyere 2015, 6523), calls for the Zimbabwe's leadership to be held accountable continue to be made. These calls have been validated by the state's behaviour of using violence as its preferred instrument of governance. Thus the creation of the ICC was viewed as a major victory for human rights especially for victims of such abuses, with many perceiving it as

\footnotetext{
I Professor in the Department of Political Sciences of the University of South Africa. Everisto does research in Human Rights, Elections, Public Opinion and Voting Behavior and Conflict Processes. E-mail: benyeeı@unisa.ac.za.
} 
a panacea to Africa's perennial challenge of human rights abuses. As a result of a captured and partisan judiciary, human rights advocates were justified in placing high hopes on the ICC to establish both historical accountability and hold individual state official liable for their actions (Chirimambowa and Chimedza 20I5, 4).

This article demonstrates the futility and complexities of bringing Mugabe to The Hague to answer to allegation of genocide and crimes against humanity. The issue of the immunity of state officials is unpacked and presented as a contested and unsettled matter which is still very fluid both in practise and at scholarship. The method adopted is an exploration of the various litigations and efforts to Mugabe before the ICC and other courts of law elsewhere. A discussion of these cases will be preceded by an exploration of the various attempts at bringing Mugabe before the ICC for prosecution and the status of his immunity from prosecution. This will be achieved by analysing the Rome Statute's Articles I7, 26 and 27; the Constitution of Zimbabwe and other relevant treaties that deal with the issue of the immunity of state officials from prosecution as well as customary international law. It is the severity of the allegations being levelled against Mugabe that calls for his prosecution have mounted over the years. That desirability notwithstanding, Mugabe's prosecution at The Hague is a complex matter, one sitting at the intersection of law and politics.

\section{ICC jurisdiction and human rights abuses in Zimbabwe}

The challenge in jurisdiction facing the ICC in Zimbabwe is that the Rome Statute restricts the Court to investigating only crimes committed after July 2002. This implies that the most contentious periods in Zimbabwe's violent past lie outside the legal mandate of the ICC. These periods include the War of Independence (1965 - I980), Operation Gukurahundi (1982 - I983), part of the land redistribution related violence $(2000-2005)$, and Operation Murambatsvina (2002). For the majority of the black population who lived under the white minority government of Rhodesia, the omission of the colonial period from the ICC's jurisdiction is a travesty of justice tantamount to the promotion of impunity. Various other challenges have been encountered in attempting to prosecute Mugabe. Despite these challenges, referrals of Zimbabwe to the ICC was attempted by many countries, institutions and even individuals with no success. The biggest stumbling block was encountered in the United Nations Security Council (UNSC) where permanent member China and rotational non-permanent member South Africa consistently refused that the case of Zimbabwe be put on the UNSC agenda. However, this was not 
the first time that Zimbabwe's case was brought before the ICC. Since 2005, various calls were made for the human rights situation in Zimbabwe to be referred to the Court by the UNSC. These include the landmark case brought by Adella Tachiona in the United States (Tachiona and Others versus Mugabe and Others. Case number: ooCIV6666VMJCF United States District Court of New York). Other failed attempts to have Mugabe indicted include the attempt by then Australian Foreign Minister Alexander Downer to lobby the UNSC to indict Mugabe, the International Bar Association's executive director Mark Ellis, the then British Ambassador to the UN, Emyr Jones Parry, the then British Foreign Secretary David Miliband when he addressed the UNSC on I4 December 2008.

Regionally, the Namibian National Society for Human Rights (NSHR) through its Executive Director Phil ya Nangolo, also tried to have Mugabe arrested in Windhoek, Namibian in 2007. The South African position regarding Mugabe is premised on SA's International Criminal Court Act 27 of 2002. It is on this legal basis that The Southern African Litigation Centre and the Zimbabwe Exiles Forum took the National Prosecuting Authority (NPA) and the South African Police Services (SAPS) to the North Gauteng asking the court to compel them to arrest Mugabe and any of his top officials should they pass through South Africa. Finally the official opposition in South Africa, in 2008, the Democratic Alliance also attempted to have Mugabe indicted at the ICC when their then leader Hellen Zille wrote a letter to UN Secretary General Ban Ki-Moon and copied to other institutions and governments such as the then UNSC chair (USA), the UN Commissioner for Human Rights, Human Rights Watch and Amnesty International. All this notwithstanding, Mugabe never appeared before the ICC; neither are there any serious current attempt to do so. This point to some complexities regarding the Mugabe ICC issue which this paper will unpack starting with the Principle of Complementarity in international criminal justice system.

\section{Complementarity and international criminal justice in Zimbabwe}

The ICC operates on the Principle of Complementarity which makes it the duty of every state to exercise criminal jurisdiction over those responsible for international crimes (Rome Statute: Articles I and I7). This is an improvement on the former ad hoc International Criminal Tribunals in Sierra Leone, Rwanda and the former Yugoslavia, which had primacy over national courts. The Principle of Complementarity works better when the ICC initiates 
investigations in states that would have proved unwilling or unable to carry out prosecutions on their own (Burke-White 2005). On the other hand, the Principle appears ill equipped and inadequately prepared to deal with cases where countries do self-referral. The Principle of Complementarity assumes that countries will be reluctant to refer themselves to the ICC. With that in mind, the Rome Statute addressed the likely scenarios of countries claiming state sovereignty and thereby refusing to be subjected to the court's jurisdiction. This left the ICC in a quandary when the opposite happened. As of December 20I2, four out of the five African cases were all self-referrals (DRC, Uganda, Central African Republic, and Sudan (Darfur) plus Sudan which was referred by the UNSC in 2005 .

With respect to Zimbabwe, it has been argued that there may be cases where inaction by states is the appropriate rationale of action by the ICC (Stigen 2008, I99; Kleffner 2008, I04). The ICC added a third dimension to the Principle of Complementarity which is inactivity/inaction. According to Stone (2OII, 325), this decision and its interpretation of Article I7 of the Rome Statute will probably not change the situation. Adding a third dimension test of 'inactivity' or 'inaction' beyond 'unwilling' and 'unable' was criticised by Schabas (2008, 73I), among others as vague and open to abuse by powerful nations. However, it is this third prong test of 'inactivity' or 'inaction' which has the potential to be used by the 'international community' to bring cases of human rights abuses in Zimbabwe to The Hague as evidence suggests that there were no genuine attempts by the government in Zimbabwe to investigate alleged cases of gross violations of human rights. The refusal by the Zimbabwe government to make public several human rights abuse reports is a case in point. Unreleased reports include the I983 Zimbabwe Commission of Inquiry into the Matabeleland Disturbances (also known as the Chihambakwe Commission of Inquiry) and the Commission of Inquiry into events surrounding Entumbane I and 2, otherwise known as the Dumbutshena Commission of Inquiry. The latter's mandate was to look into the clashes between former Zimbabwe African National Liberation Army (ZANLA) and Zimbabwe People's Revolutionary Army (ZIPRA) forces at Entumbane and the killings in Matabeleland in I983 (Raftopoulos and Eppel 2009, I3). The now almost defunct Human Rights Commission serves as a further example of Zimbabwe's unwillingness to investigate human rights abuses. Unwilling because the state failed to support the Zimbabwe Human Right Commission into functionality (Chiduza 2015, I48-I74).

This section grapples with the possibility of Zimbabwe's alleged human rights violations being taken to the ICC as a result of evoking the Principle of Complementarity. This is highly unlikely given the vagueness of this 
Principle which instead of revealing which cases the ICC should investigate, sets out instead the specific cases the ICC should not investigate or prosecute (Rome Statute Articles I7 and 53). There are three sets of crimes which the ICC does not concern itself with. These are: firstly, those international criminal cases which states with jurisdiction over them are already investigating or prosecuting, as evidenced by a display of genuine willingness and ability to do so. Secondly, the ICC does not consider cases where the crimes in question are not regarded as serious enough to concern the ICC, and finally those cases where an investigation would not serve 'the interests of justice' (Kleffner 2008, 292). Under these circumstances, victims' interests become secondary to the primary concerns of investigation, conviction and punishment of the perpetrators. The inclusion of the 'the interests of justice' as a major selection criterion further diminishes the interests of victims in general and the need for reconciliation in particular.

Another challenge with the Principle of Complementarity is the lack of clarity on what constitutes sufficient gravity. This clarity is important for the Mugabe indictment because it has a bearing on the classification of the severity of the allegations he faces, hence the likelihood of his indictment. The ICC Office of the Prosecutor has yet to define exactly what constitutes 'sufficient gravity' and what 'the interests of justice' entail (Schabas 2007, I86, 4I5; Clark 2008, 37-46). According to Clark, the Prosecutor outlined four main criteria for determining the gravity of crimes. These are their scale, nature, the manner of their commission, and their impact. The criteria for the assessment of these circumstances have yet to be developed implying that, in the meantime, some alleged perpetrators like Mugabe remain free. It can be concluded that rather than prosecuting suspects of gross violations of human rights, the ICC's Rome Statute is more concerned with preserving the sovereignty of certain states, particularly those opposed to its formation such as the USA. This is evidenced by the ICC's case selection criteria which is the subject of discussion in the next section.

\section{ICC case selection}

How the ICC chooses the cases it investigates is central both to its international criminal justice and its success as a court. Its prosecution record indicates the need to balance law and politics of its case selection. The ICC is caught between an idealistic vision of a global court designed to prosecute the cases that domestic jurisdictions cannot or would not prosecute. This was compounded by the pragmatic concerns of the ICC as a fairly new institution seeking judicial results to secure its legitimacy. Under these circumstances, 
case selection is a key ingredient in the ICC's endeavour to build a strong legal corpus and create legal precedent. According to the Rome Statute, situations can be referred to the ICC in one of three ways: first, by a state party; secondly, by the UNSC; and thirdly at the instigation of the Prosecutor. In the third scenario, the Prosecutor must gain the authorisation of the Pre-Trial Chamber of the Court before launching investigations and must show that there are sufficient grounds to do so (Rome Statute: Articles 54 and 56).

According to Clark (2008), more than Io years into its existence the ICC is still developing its broad strategy for case selection based on the rules outlined in the Rome Statute and its Principle of Complementarity. For Clark, three trends in the Prosecutor's approach emerged. Firstly, the Office of the Prosecutor indicated that it would focus on perpetrators who bore the greatest responsibility for international crimes. This means that the OTP is likely to prosecute only government, military or militia leaders suspected of orchestrating or committing crimes under the ICC's jurisdiction. This renders Mugabe a typical suspect for prosecution. However, the challenge inherent in this approach is the determination of who decides which suspect 'bears the greatest responsibility' for the crimes allegedly committed. Should it be the victims or the Prosecutor? Does the Prosecutor have the competence to adjudicate and apportion responsibility in crimes that he or she did not witness? Most importantly, whose word or what kind of evidence will the Prosecutor use to arrive at such a decision? These considerations work against the successes of the ICC's case selection and inversely feed the growth of impunity, by providing a technical loophole which results in the non-prosecution of suspects like Mugabe.

The second legal technicality concerns the OTP's outsourcing of one of its key functions, i.e., bringing suspects before the court for prosecution. In a statement the then ICC prosecutor Luis Mareno Ocampo stated that the ICC, 'will encourage national prosecutions, where possible, for the lower-ranking perpetrators, or work with the international community to ensure that the offenders are brought to justice by some other means' (Stahn and Sluiter 2009, 220).

This process is meant to result in the prosecution of small numbers of high-level perpetrators, while encouraging domestic jurisdiction to help close any potential 'impunity gap' left by the ICC's focus on minority high profile suspects such as Mugabe. This presents some challenges contained in the grading and ranking of crimes and criminals as there is no agreed instrument, tool or criteria with which to do this, leaving such an important aspect open to different interpretations and a lot of contestations. Thirdly, the OTP indicated that it would take an extremely cautious approach to selecting 
which cases to investigate, acting only when it possessed enough evidence to provide strong prospects for a successful investigation. It is likely then that the OTP will pursue cases only where state parties and other sources have already gathered substantial evidence. This reliance on third parties for such crucial aspects such as the gathering of evidence is undesirable for the ICC. Outsourcing of evidence collection weakens the ICC as the motives for evidence collection differs, especially when this is done by those linked to the suspects or the victims as aptly demonstrated in the collapse of the Uhuru Mugai Kenyatta versus the Prosecutor case (ICC-OI/O9-O2/II).

\section{Zimbabwe's position regarding the ICC jurisdiction}

Zimbabwe's official position regarding the calls for the prosecution of its President deserves to be considered in a discussion of this nature. In a seemingly dismissive manner, Zimbabwe consistently treats attempts to have Mugabe indicted as foreign meddling in its internal affairs sponsored by its detractors pursuing regime change agenda. The President's Press Secretary, George Charamba, said that calls for Mugabe's indictment were attempts to tarnish the image of the President and the country. Charamba noted that Zimbabwe was not a signatory to the Rome Statute that had created the ICC and was therefore not legally bound by its dictates (Voice of America News, 3I October, 2009). In an interview with the author on 24 September 20I2, the same views were expressed by the then Deputy Director of the Organ on National Healing, Integration and Reconciliation, Anderson Chiraya, who stated that the ICC had no role in Zimbabwe. He observed that the ICC was a foreign organ with no jurisdiction over Zimbabwe, or any Zimbabwean for that matter, just as it had no jurisdiction over the United States of America, Israel, any American or Israeli. For him, the irrelevance of the ICC to Zimbabwe is illustrated by the fact that Zimbabwe was never part of the ICC and, according to him, never would be. He gave the selective application of law and the deliberate targeting of Africa, especially its leaders, as the reason for Zimbabwe's resentment of the ICC. This response aptly sums up Zimbabwe's official position on the matter.

It is worth noting that the unlike the former ad hoc international criminal tribunals which were established by UNSC resolutions hence had the backing of Chapter VII measures, the ICC is a treaty based court and its existence rests upon the direct consent of contracting states (Gaeta 2009, 319). This presents a major challenge to contracting states when requested to effect warrant of arrests as the apprehension of such heads of states will be against customary international law and in some cases in contravention of these 
countries' domestic law. Such a dilemma was faced by South Africa when al Bashir visited South Africa in June 20I5.

\section{Mugabe and immunity from ICC prosecution}

One of the central questions which this article seeks to answer is whether Mugabe has immunity from prosecution at the ICC or any other domestic court of law. International criminal law is very unambiguous on this position with Article 27 (2) of the Rome statute stating that, 'immunities or special procedural rules which may attach to the official capacity of a person, whether under national or international law, shall not bar the Court from exercising its jurisdiction over such a person'. However the position of state official immunity is a very much contested principle under domestic law. According to Gaeta $(2009$, 318) more clarity on the issue can be established if the status of the customary rule of international law on immunities of heads of states equally applies to international criminal courts. Historically this matter was ruled upon by the International Court of Justice in the Democratic republic of Congo versus Belgium (I4 February 2002). The court ruled that personal immunities applied only to national courts and not international criminal courts, thereby validating Article 27(2) of the Rome Statute. That precedent setting ruling notwithstanding attempts were made to test Mugabe's immunity in various courts.

The first test of Mugabe's immunity from prosecution on allegations of gross human rights abuses was a case discussed earlier on which was brought before the United States District Court, New York on the 7 th of August 2002 by Talent Chiminya, widow of Tichaona Chiminya who was killed together with fellow MDC activist Talent Mabika on I5 April 2000 (Blair 2002, 258). The allegations by Talent Chiminya were that Mugabe in his capacity as the leader of ZANU PF was responsible for her husband's death who was allegedly killed by his party's officials. Amnesty International's 2002 report, titled Zimbabwe the toll of impunity, reported that the two were killed by Central Intelligence Organisation (CIO) agent Joseph Mwale and war veteran Kainos Tom 'Kitsiyatota' Zimunya, who was commanding a group of ZANU $\mathrm{PF}$ youths who carried out the murder. In the case, Mugabe's defence was predicated on his immunity from prosecution which the US court upheld, ruling that such a position was consistent with international practice, i.e., International Criminal Law.

The above judgement can best be understood if the two types of immunity that the ICC considers in such cases are explained; functional immu- 
nity and personal immunity. Functional immunity is commonly referred to as immunity ratione materiae while personal immunity is called immunity ratione personae (Akande and Shah 20I0, 8I7). Personal immunity or ratione personae is attached to senior state officials while they are still in office. State as well as judicial practice indicates that this form of immunity applies even to international crimes, as held by domestic courts in cases involving former Libyan leader President General Muammar Gaddafi and Mugabe. The principles of immunity ratione materiae and immunity ratione personae were also discussed in the following cases: Jones $v$ Ministry of the interior of the Kingdom of Saudi Arabia [2006] UKHL 26, [2007], Bat v Investigating Judge of the German Federal Court [2011], EWHC 2029 (Admin) and Sosa v Avarez-Machain, 542 U.S. 692 (2004).

It can be deduced from these cases that functional immunity or ratione materiae can be invoked not only by serving state officials but also by former state officials in respect of their official acts while they were in office. This implies that Mugabe can claim this type of immunity even when he is no longer in power. The norm is that the state of the accused is allowed to choose whether or not its agents would be responsible under international law for crimes they allegedly committed while still in office. Therefore it is the state's responsibility to determine the status of its official's claim to immunity. Should Mugabe be out office and still be alive, that call will have to be made by the government of the day. In all likelihood, the revoking of this immunity will only become a possibility with a change of administration in Zimbabwe.

In principle, the ICC becomes involved in cases where states abuse their sovereignty and fail to address impunity. Many countries in Africa have constitutional provisions that provide immunity from prosecution for their presidents or, in some cases, their prime ministers. These provisions include Section 30 of the Constitution of the Republic of Zimbabwe (Presidential Immunity); Article 46 of the Constitution of the United Republic of Tanzania, 1977 (as amended); Article 98 of the Constitution of the Republic of Uganda, 1995; section 34(1)-(5), First Schedule to the Constitution of the Republic of Ghana, 1992; Constitution of the Fourth Republic of Ghana Law, 1992, sections 28(1), 34 and 35(1)-(3); Constitution of the Kingdom of Swaziland, Article 61; Constitution of Liberia, Article 48(4) and Constitution of the Republic of Sierra Leone, 1991.Despite the existence of these constitutional provisions, international criminal law on non-recognition of the immunity of state officials for international crimes exists in the form of Article 27 of the Rome Statute. This Article sets out the position in international criminal law of the prosecution of individuals for international crimes before international courts. Zimbabwe should therefore not trust its domestic immunity provisions since a precedent was already set 
with the indictment of al Bashir. That precedent notwithstanding, some leaders with terrible human rights abuse records, such as Uganda's Amin and Museveni, UK's Tony Blair, USA's George W. Bush, Uganda's Yoweri Museveni, Russia's Vladmir Putin, Syria's Bashar al Assad and DRC's late Mobuto Sese Seko, were never indicted by any international legal institution.

Zimbabwean politicians interpret Section 30 of the Constitution as conferring the President with immunity from prosecution wherever and whenever. This is contrary to Subsection I (b) of the same Constitution which allows for the President to be held liable for his/her personal actions. Section 30 of Zimbabwe's Constitution reads:

(I) The President shall not, while in office, be personally liable to any civil or criminal proceedings whatsoever in any court. (2) Without prejudice to the provisions of subsection (3), it shall be lawful to institute civil or criminal proceedings against a person after he has ceased to be President, in respect of - (a) things done or omitted to be done by him before he became President; or (b) things done or omitted to be done by him in his personal capacity during his term of office as President.

The above contradiction in law warrants clarification by a competent legal entity, probably the whole bench of the Supreme Court of Zimbabwe. Such a clarification leaves no room for speculation and personal interpretation of the law regarding the Mugabe's immunity from prosecution in Zimbabwe and elsewhere.

At continental level, there is no legal framework which either outlaws or upholds the immunity of state officials in Africa. The African Union only has provisions that merely condemn impunity (Article 4(o): Constitutive Act of the AU). Article 4 of the AU's Constitutive Act contains the principle which is central to outlawing impunity in Africa as it allows the AU the right to intervene in a member state pursuant to a decision of the Assembly of Heads of States and Governments of the Union in respect of grave circumstances, namely: war crimes, genocide and crimes against humanity (Article 4(h): Constitutive Act of the AU). While such a provision exists, its enforcement remains a distant reality despite the regular occurrence of war crimes, genocide and crimes against humanity in Africa.

There are numerous shortcomings inherent in this regional impunity prevention mechanism which makes it untenable in stopping impunity in Zimbabwe. The major shortcoming of this mechanism is that it makes no provisions for enforcement, thereby rendering it ineffective at law. According to Murungu (20II, 65), Article 4(h) does not have an express mandate to pros- 
ecute individuals who commit international crimes in Africa. This loophole is manipulated by African leaders who are liable for censorship by the AU for war crimes, genocide and crimes against humanity but are never cautioned owing to this shortcoming. Murungu further contends further that it is also difficult to infer whether intervention would include prosecution of perpetrators of international crimes in Africa. Another flaw in the AU's anti-immunity provisions is that nowhere is it specifically provided in the Constitutive Act that an African state official may be prosecuted for international crimes. This implies that the AU's official and legal position on the international crimes of genocide, war crimes and crimes against humanity remains vague. The existence of the legislation notwithstanding, it can be argued that there is no African country with the political will to bring Mugabe before the AU to answer to allegations of gross violations of human rights as outlined in Article 4 of the AU's Constitutive Act. It can be further argued that, if the solidarity shown by the AU in rallying behind ICC accused Sudanese President Omar al Bashir is anything to go by, the chance that the AU will act on Zimbabwe becomes extremely slim, if not non-existent.

At another level, an analysis of the sub-regional's (SADC) legal framework reveals a similar lack of legal instruments to fight executive impunity. It is debatable whether this absence is deliberate on the part of regional leaders or not. Not surprisingly, Zimbabwe is not a member of the International Conference on the Great Lakes Region of 29 November 2006 which passed the only protocol in Africa which explicitly condemns impunity. Zimbabwe is therefore not a part of the Protocol for the Prevention and the Punishment of the Crime of Genocide, War Crimes and Crimes against Humanity and all forms of Discrimination signed on this date. Members to the protocol are Angola, Burundi, Central African Republic, Republic of Congo, Democratic Republic of Congo, Kenya, Uganda, Rwanda, Sudan, Tanzania and Zambia. The Protocol is based on the Convention on the Prevention and Punishment of the Crime of Genocide which was adopted by Resolution 260 (III) A of the United Nations General Assembly on 9 December I948 and the Rome Statute of the ICC of I July 2002. The relevant section of the Protocol is Article I2 which is almost a verbatim duplication of Article I7 of the Rome Statute which reads:

The provisions of this chapter shall apply equally to all persons suspected of committing the offences to which this Protocol applies, irrespective of the official status of such persons. In particular, the official status of a Head of state or Government, or an official member of a Government or Parliament, or an elected representative or agent of a state shall in no way shield or bar their criminal liability (Article I2: Protocol for the Prevention and the Punishment of the Crime of Genocide, War Crimes and Crimes Against 
Humanity and all forms of Discrimination).

It is imperative to note that the provision specifically mentions that official capacity, especially Head of State, does not exempt one from prosecution. Article 27 (I) of the Rome Statute states that:

This Statute shall apply equally to all persons without any distinction based on official capacity. In particular, official capacity as a Head of State or Government, a member of a Government or parliament, an elected representative or a government official shall in no case exempt a person from criminal responsibility under this Statute, nor shall it, in and of itself, constitute a ground for reduction of sentence.

Article 23 lays down the mandates of member states, including the duty to cooperate with the ICC. Section (a) specifically mentions cooperation with 'requests to the arrest and hand over of persons alleged to have committed crimes falling within the jurisdiction of the ICC'. The provisions of this Protocol, unlike those of the AU's Constitutive Act, are very clear on their mandate, their relationship with the ICC and on which crimes should be dealt with and in what format. It remains to be investigated whether the Protocol for the Prevention and the Punishment of the Crime of Genocide, War Crimes and Crimes Against Humanity and all forms of Discrimination was an attempt by certain African countries to circumvent the AU by charting an alternative, decisive, unambiguous way to deal with impunity in Africa.

The AU's Constitutive Act almost abdicates the outlawing of impunity to national legislations, their well-documented lack of capacity and political will notwithstanding. At state level, very few African countries have legislation addressing executive impunity. These countries include South Africa, Uganda, Senegal, Burkina Faso, Niger, Kenya, Congo, Burundi, Rwanda and Ethiopia. Recent developments in South Africa brought hope to those seeking to prosecute Mugabe and his fellow senior party officials. In a landmark lawsuit (SALC and Another v NDPP and Others case 77150/09), of March 2012, the North Gauteng High Court decided that the South African National Prosecuting Authority (NPA) was expected to prosecute any Zimbabwean accused of violating human rights in Zimbabwe should they come to South Africa. According to the South African Litigation Centre's (SALC) website (visited on I3 February 20I3), the facts of the matter were that, 'the NPA and South African Police Services (SAPS) refused to initiate an investigation and SALC and the Zimbabwe Exiles Forum took this decision on review to the High Court'. On 8 May 2012 Judge Hans Fabricius delivered judgement in SALC's favour, 
in which the High Court ordered the NPA and SAPS to initiate investigations into human rights abuses by the I 8 Zimbabwean security officials cited in the case. From this it can be construed that in the absence of continental and regional legal frameworks to try those accused of impunity, reliance on national legislation like that of South Africa becomes the only realistic hope for the prosecution of those suspects. The existence of that legal framework notwithstanding, chances that the SAPS and the NPA will arrest Mugabe are unlikely given the cordial relations between ZANU PF and the African National Congress which date back to the colonial/apartheid era.

Beside South Africa, Ethiopia also set a promising legal precedent when it prosecuted its former President, Mengistu Haile Mariam, finding him guilty and sentencing him to death, albeit in absentia, ironically holed up somewhere in Zimbabwe. On a more positive note, the African Court of Justice and Human Rights sought to establish a Chamber with jurisdiction over persons who commit international crimes in Africa. Like the ICC, the African Court of Justice and Human Rights is a noble idea that can only be evaluated once it has been implemented. At the moment, hope of ending impunity in Africa remains with the ICC. However, the ICC needs to undergo a metamorphosis of some sort if it is to become more relevant and appealing, especially to victims of gross human rights violations in Africa.

\section{Conclusion}

The article demonstrated that transitional justice evolved from its early conceptualisation as a form of criminal justice, to a more complex, multi-dimensional and responsive phenomenon. As policymakers gain greater understanding of the causes of conflict and the nature of political, social and economic transition, it is inevitable that transitional justice processes will be increasingly called upon to address economic, social and cultural rights. The general conclusion reached is that the ICC lags behind and risk being irrelevant to the transitional justice agenda, especially in Africa where its credibility and track record is seen to be unconvincing, mostly by victims of human rights abuses. The government of Zimbabwe was not a signatory to the Rome Statute and therefore not a member of the ICC and does not recognise the ICC. However, this does not imply that the ICC is not in a position to act on Zimbabwe. As exemplified by the indictment of Sudanese President Omar al Bashir, where Sudan is not a member of the ICC, the Court could act on a referral from the UNSC to investigate a non-member state.

Other reasons for this inability to act on Mugabe relate to the ICC's ju- 
risdiction in which cases committed prior to the entry into force of the Rome Statute in 2002 are considered out of the court's ambit. Also noted as problematic was the ICC's occupation of a secondary role in which national judiciaries assume the first court of appeal status. This is untenable for victims of gross violations of human rights in Zimbabwe, as the state which was expected to lead the investigations is the prime suspect. The complexity of international law, especially international jurisprudence, renders the ICC a complex and implausible solution to local reconciliation needs. Besides the complexities at the ICC level, other challenges which render Mugabe's prosecution unlikely were noted. These include the AU's lukewarm attitude towards executive impunity and the continental statesman status Mugabe enjoys in Africa. In all likelihood, Mugabe will never face prosecution at the ICC or any court of law to answer to allegations of genocide and crimes against humanity, especially for the $1982 / 3$ genocide which he presided over.

\section{Post scriptum: Of old realities being reinforced by new developments}

As of 2I November 20I7, Robert Mugabe was no longer the President of Zimbabwe. He was ousted by a combination of peaceful popular uprising and a military led uprising within his own ruling ZANU PF party. This after he had unceremoniously dismissed his Deputy President and now President of Zimbabwe Emmerson Dambudzo Munangagwa. Now that Mugabe is no longer in power, does this change the script? I am not convinced that Mugabe's change in political fortune will see him having his day in court, in Zimbabwe, The Hague or anywhere. This is because of what I term old realities being reinforced by new developments.

The old realities are three fold. Firstly, Zimbabwe is not part of the Rome Statute. In addition, the biggest and worst crime which Mugabe is accused of presiding over falls outside the jurisdiction of the ICC, i.e., Gukurahundi genocide was committed in $1982 / 3$ and the ICC only concerns itself with crimes committed after 2002 when the Rome Statute came onto force. Secondly, at home, the judiciary system is still the same, unreformed, partisan and for all intends and purposes captured by the ruling party, ZANU PF.

Thirdly, Britain is complicit in the Gukurahundi genocide in that the Margaret Thatcher administration was aware that a genocide was occurring in Zimbabwe but they kept their silence. Two occasions were propitious for Zimbabwe's former colonisers to castigate the genocide and call international attention and intervention before the situation deteriorated. At the Common- 
wealth Heads of Government Meeting in New Delhi, India, between 23 and 29 November 1983 and when the then British Foreign Office Minister Malcolm Rifkind held diplomatic consultations with Mugabe, in November I983. Thus, the British were complicit and they will not mind to have Mugabe's genocide prosecution calls die a natural death.

Then to the new developments which reinforce the old realities. Firstly, Mugabe is still immensely respected by the 'new' ZANU PF leadership. That the new leadership declared Mugabe's birthday, 2I February as a national holiday attests to their continued admiration of their former leader. President Munangagwa also publicly praised Mugabe for his contributions to Zimbabwe. The United Nations Security Council (UNSC), The United States of America and the US President Donald Trump are busy with Iran, Palestine/ Israel, Syria, the Russian Federation and other 'more important' geopolitical and global issues and Zimbabwe is far from being part of the UNSC agenda any time soon.

Thirdly, those accused of being with Mugabe at the forefront of masterminding and committing the genocide are now key office bearers in the post-Mugabe Zimbabwe administration. Then Firth Brigade Commander, Air Chief Marshal Perence Shiri is now the Minister of Lands, Agriculture and Rural Resettlement, Former Defence Forces Commander, General Constantino Guveya Dominic Nyikadzino Chiwenga is now the Vice President and the then Minister of State Security Minister Emmerson Munangagwa is now the President. The roles (real or perceived) played by Munangagwa, Chiwenga, Shiri and many others during Gukurahundi and the entire Mugabe period renders Mugabe's prosecution unlikely. Surely, given the combination of the above, Mugabe will not face any prosecution for the four crimes of genocide; crimes against humanity; war crimes; and the crime of aggression.

Lastly, there are constitutional provisions which make the prosecution of a former head of state virtually impossible. Chapter 5, Part I, Section 98, Subsection $2 \& 4$ reads:

(2). Civil or criminal proceedings may be instituted against a former President for things done and omitted to be done before he or she became President or while he or she was President ...

(4). In any proceedings brought against a former President for anything done or omitted to be done in his or her official capacity while he or she was President, it is a defence for him or her to prove that the thing was done or omitted in good faith.

The manner in which subsection 4 is worded gives the president de- 
fence in case of prosecutions for his c/omissions while in office. This subsection is therefore pre-emptive and indicative of the likely judgement in case of a prosecution, i.e., that such c/omissions were done in good faith.

So, is all hope for the victims of human rights abuses in Zimbabwe lost? What can the post-Mugabe government do? There are three options for the Munangagwa administration to address this issue. Firstly, they can officially release the both the Chihambakwe and the Dumbutshena Commission reports. Secondly, Munangagwa on behalf of ZANU PF and government can blanketly admit culpability for crimes committed, just like Nelson Mandela did when on the 23rd of August I993, the Motsuenyane Commission reported that the African National Congress (ANC) was guilty of torture in its camps and that specific individuals were responsible for these abuses. Instead of holding individual ANC and Umkhonto weSizwe members culpable, Mandela took all the responsibility. Lastly, the government can initiate restorative justice programmes. These have to be conceived and agreed upon by the various communities that were affected by the various human rights abuses and not only the genocide. This will give some respite to those victims and communities who want to forgive and move on, yet they have no one to forgive.

\section{REFERENCES}

AidData. 20I7. Tracking Chinese Development Finance - BETA, Accessed August 20I7. http://china.aiddata.org/.

Amante da Rosa, M. 2007. "Geoestratégia de Cabo Verde no Atlântico Médio", Revista Direito e Cidadania, nffl 25/26, I63-187.

Anshan, L. 2007. "China ad Africa: policy and challenges", China Security, 3, nffl 3, 69-93.

António, N. S. 2008. Economia e Gestão Chinesas, Aspectos Fundamentais. Lisboa: Edições Sílabo.

Banco Mundial. 20I7. O Banco Mundial em Cabo Verde - Dados. Acessado em setembro de 20I7. https://data.worldbank.org/country/cabo-verde

Brautigam, Deborah. 2008. China's foren aid in Africa: What do we know? In China into Africa: Trade, aid and influence, edited by Rotberg, R. Washington, DC: Brookings Instituion Press.

Chichava, S. 2008. Mozambique and China: from politics to business? Discussion paper no. 05/2008, Maputo, Instituto de Estudos Sociais e Económicos. 
Cooley, J. I965. East Wind over Africa: Red China's African offensive. New York: Walker and Company.

Eisenman, J. 20I5. China's post-cold war strategy in Africa: Examining Beijing's Methods and Objectives. In China and the Developing World: Beijing's Strategy for the Twenty-first Century, edited by Eisenman, J., Heginbotham, E. and Mitchell. D. New York: Routledge.

Gonçalves, W.da S. 2oıo. A presença da China na África. In Segurança Internacional: Perspectivas Brasileiras, organized by Jobim, N., Etchegoyen, S. W. and Alsina, J. P. Rio de Janeiro: FGV.

Governo da Região Administrativa Especial de Macau (RAEM). Plano de Ação para a Cooperação Económica e Comercial de 2003. Fórum para a Cooperação Económica e Comercial entre a China e os Países de Língua Portuguesa (FCECCPLP). Acessado em agosto de 20I7. http://www. forumchinaplp.org.mo/action-plans/strategic-plan-for-economicand-trade-co-operation-approved-in-2003/?lang=pt

Governo da Região Administrativa Especial de Macau (RAEM). 20I7. Fórum de Macau. Acessado em agosto de 20I7. http://www.forumchinaplp. org.mo/about-us/mission-and-objectives/?lang=pt

Hackenesch, C. 20II. Competing for development? The European Union and China in Ethiopia. Stellenbosch: Centre for Chinese Studies at the University of Stellenbosch.

Hong-Ming, Z. 2004. A política chinesa na África. In Abrindo os Olhos para a China, organized by Bellucci, B. Rio de Janeiro: Centros de Estudos Afro-Asiáticos, Universidade Cândido Mendes.

Instituto de Promoção e do Investimento de Macau (IPIM). 20I5. China é o segundo maior investidor em Moçambique. Acessado em agosto de 2017. http://www.ipim.gov.mo/pt-pt/portuguese-speaking-countries-newspt-pt/china-e-o-segundo-maior-investidor-em-mocambique/.

Jackson, T. 2004. Management and Change in Africa: a cross cultural perspective. London: Routledge.

Jintao, H. 2012. Open Up New Prospects for a New Type of China-Africa Strategic Partnership. Accessed august 20I7. http://mw.china-embassy.org/ eng/sghdhzxxx/t95345 I.htm

Jornal Tribuna de Macau. 20I5. 2,15 mil milhões para projecto "histórico" de David Chow. Acessado em agosto de 20I7. <http://jtm.com.mo/local/2I5-mil-milhoes-para-projecto-historico-de-david-chow/>

Kabunda, M.(org.) .20II. África y la cooperación con el Sur desde el Sur. Madri: Casa África. 
Keijzer, A. de I992. China Estratégias Para um mercado emergente. Lisboa: Difusão Cultural.

Kobylinski, K. 2012.Chinese Investment in Africa: Checking the Facts and Figures. Accessed agosto 20I7. <https://www.amo.cz/wp-content/uploads/20I5/II/amocz-BP-20I2-7.pdf>.

Kynge, J. 2006. A Ascensão de uma Nação Á vida, A China abala o mundo. Lisboa: Editorial Bizâncio.

Macauhub. 20I6. China foi o maior investidor em Moçambique no 1.ffl semestre. Acessado em agosto de 20I7. <https://macauhub.com.mo/ pt/2016/o8/ı/china-the-top-investor-in-mozambique-in-Ist-halfyear/>

Manji, F. and Marks, S. 2007. African Perspectives on China in Africa. Nairobi/ Oxford: Fahamu.

Marchionatti, W. 20I2. China: Velho e Novo Império. Porto Alegre: EDIPUCRS.

Mendes, C. A. 2oıo. A China e a Cooperação Sul-Sul, Relações Internacionais, nffl 26, 39-46.

Madeira, J. P. 20i6. Cabo Verde: De um "Estado Inviável" ao Pragmatismo na Política Externa. Revista de Relaciones Internacionales, Estrategia Y Seguridad. Vol. II. nffl I. 85-IoI.

Madeira, J. P. 20I5. Cape Verde: Geopolitics and Projection of a Small Island State in West Africa. Austral: Brazilian Journal of Strategy a International Relations, v.4, n.8, 58-77.

Michel, S. 2008. When China Met Africa, Foreign Policy, nffl ıi6, 38-46.

Morais, J. 20I5. Cabo Verde: Há condições para catapultar a parceria bilateral a novos patamares. Revista Macau, nffl 44. Acessado em agosto de 20I7. http://www.revistamacau.com/20I5/06/15/cabo-verde-ha-condicoes-para-catapultar-a-parceria-bilateral-a-novos-patamares/

Naidu, S. 2007. China-Africa relations in the 2ist century: a "Win-Win" relationship. In China in Africa, organized by Lee, M., Melber, H., Naidu, S. and Taylor, I. Uppsala: Nordiska Afrikainstitutet.

Rios, X. 2005. Política Exterior de China: La Diplomacia de una Potencia Emergente. Barcelona: Edicions Bellaterra.

Shelton, G. 2006. China, África y Sudáfrica: Avanzando hacia la cooperación Sur-Sur. In Política y Movimientos Sociales en un Mundo Hegemônico: Lecciones desde África, Asia y América Latina, organized by Borón, A. and Lechini, G. Buenos Aires: Clacso.

Snow, P. 1988. The Star Raft: China's Encouter With Africa. New York: Weidenfeld and Nicholson. 
Taylor, I. 2009. China's New Role in Africa. Boulder: Lynne Rienner Publishers.

Taylor, I. 2006. China's Oil Diplomacy in Africa, International Affairs, 82, nffl 5, 937-959.

Taylor, I. 2006. China's relations with Mozambique. In China and Africa engagement and compromise, edited Taylor, I. Londres, Routledge.

Teixeira, A., Ferreirinha, M. and Barbosa, L. 1958. A Agricultura do Arquipélago de Cabo Verde. Lisboa: Junta de Investigações do Ultramar.

The Conversation. 20I7. Where Africa fits into China's massive Belt and Road Initiative. Acessado em agosto de 20I7. <http://theconversation.com/ where-africa-fits-into-chinas-massive-belt-and-road-initiative-780I6> Acessado em I2/08/20I7.

Visentini, P. F., Oliveira, G. Z.de .20I2. As relações sino-africanas: (muitos) e mitos e (algumas) realidades: Século XXI, Porto Alegre, 3, nffl I, 25-40.

Zhao, S. 2004. Beijing's Perceptions of the International System and Foreign Policy. Adjustment after the Tiananmen Incident. In Chinese Foreign Policy: Pragmatism and Strategic Behaviour, edited by Zhao, S.. New York, London: M.E.Sharpe.

\begin{abstract}
One of the most desired actions by human rights activists the world over is to see Zimbabwe's President Robert Mugabe brought to The Hague to answer to allegations of genocide and crimes against humanity committed during his more than three decades in office. This desire notwithstanding, there are both legal and practical imperatives that render his prosecution highly improbable judging by the failed attempts to do so by various organisations. This article is a contribution to the debate on the fate of heads of states accused of genocide and crimes against humanity by focusing on the complexities surrounding the various attempts at having Mugabe brought before the International Criminal Court (ICC). The conclusion reached is that, no matter how desirable, the prosecution of Mugabe at the ICC, or any other court of law, is a distant reality due to various reasons outlined in the article.
\end{abstract}

\title{
KEYWORDS
}

Mugabe, International Criminal Court, Crimes Against Humanity, Prosecution, Zimbabwe, Immunity. 